\title{
Pardon Me: Current Avenues for the Correction of Wrongful Conviction in Australia
}

\author{
Lynne Weathered *
}

\section{Introduction}

The growing number of DNA exonerations has highlighted the problem of wrongful conviction in the United States. Wrongful conviction is, however, an international dilemma and the innocence movement, now an international one. This article offers an Australian perspective on mechanisms for the correction of wrongful conviction.

This article commences with a brief sampling of some Australian cases of wrongful conviction, demonstrating the existence of the problem in this country, and highlighting the length of time and difficulties that can be experienced in achieving an exoneration. Part two of this paper analyses the corrective mechanisms for claims of actual innocence. It focuses on the inadequacy of current Australian appeal and pardon provisions dealing with such cases that rely on new evidence of innocence.

\section{Wrongful Conviction: An Australian Dilemma too}

The problem of wrongful conviction has been most notably highlighted through the recent spate of DNA exonerations in the United States, with 157 at the time of writing (Innocence Project October 282005 ). Based on this information, Australians tend to accept readily that wrongful conviction is a considerable problem in the United States. At the same time, there appears to be some reluctance to concede that our own criminal justice system also convicts innocent persons, at least to the same extent as occurs in the United States.

* Lynne Weathered is the Director of the Griffith University Innocence Project and the Executive Director of the Australian Innocence Network. She is a lecturer at Griffith University Law School, Gold Coast Campus, Queensland, Australia. Her doctoral thesis examines Institutions and Mechanisms for the Correction of Wrongful Conviction with Recommendations for Queensland and Australia. The author wishes to acknowledge the important research assistance provided by Kobie Mulligan in the production of this article. She also wishes to thank Professor Eric Colvin of Bond University and Jason Murakami, co-founder of the Griffith Innocence Project and Senior Associate, Nyst Lawyers, for their valuable feedback on earlier drafts of this article. The views expressed in this article are those of the author and not necessarily those of the Innocence Project and/or the Australian Innocence Network. Postal Address: Griffith University Law School Gold Coast Campus GU PMB 50 Gold Coast Mail Centre 9726 Australia Phone: 61 - 755528527 Fax: 61 -755528667<1.weathered@griffith.edu.au>. 
This conclusion appears to be based on the belief that Australia's criminal justice system offers more protections against wrongful conviction than that in the United States. ${ }^{1}$ While this may be true, Australia's criminal justice system also has significant similarities to that in the United States. Both are adversarial systems that have police, prosecutors, defence lawyers, judges and juries all playing vital roles within the system.

Further, other common law jurisdictions such as Canada and England have experienced their own cases of wrongful conviction (For a Canadian example see Kaufman 1998; for a United Kingdom example see Royal Commission on Criminal Justice 1993).

Australia may wish to pay particular attention to the English experience, where via the recently established Criminal Cases Review Commission (CCRC) approximately two hundred cases have been referred to the Courts of Appeal, resulting in $64 \%$ of convictions being quashed and $83 \%$ of sentences being been varied (CCRC 2003:24). Australia already offers its own examples of wrongful conviction.

\section{Australian cases of wrongful conviction: a sampling}

The following briefly reviews just three of the known cases of wrongful conviction that Australia has witnessed, and outlines the processes and mechanisms that applied to the cases in achieving their exonerations.

\section{Lindy and Michael Chamberlain}

\section{Brief Summary}

Convicted of the murder of her baby while the family was holidaying in the Northern Territory, Lindy Chamberlain was the subject of one of the most high profile cases this country has witnessed, as well as the subject of the movie and book, 'Evil Angels'. Her husband, Michael, was also convicted of being an accessory after the fact, as it was alleged that he helped Lindy dispose of the body (Chamberlain and Another $v R$ ).

From the outset Chamberlain claimed that a dingo had taken her baby, Azaria, from the family tent. This account was seemingly scoffed at by the public, media and jury alike. However, a Royal Commission established in 1986 to investigate the convictions, concluded that the evidence afforded considerable support for the view that a dingo might have taken the baby, additionally concluding that the expert scientific evidence presented at trial, significantly contributed to the wrongful convictions (Re Conviction of Chamberlain at 247). Of particular importance was the evidence of a forensic biologist who testified that a 'significant' amount of foetal blood was present in the Chamberlain's car. It was later found that there was a strong probability that the 'blood' was actually 'sound deadening compound' containing no blood at all (Morling 1987:106).

\section{Exoneration Process}

From 1980-1981 a coronial inquiry into death of Azaria Chamberlain was held, concluding that a dingo most likely took the baby, not that Lindy Chamberlain had murdered her (Brown \& Wilson 1992:125). Subsequent evidence gathered by police, the evidence of a 'handprint' on Azaria's jumpsuit, and scientific 'blood evidence' led to the quashing of the coroner's inquest, and a new inquest was ordered. The inquest opened 14 December 1981, and on 2 February 1982, the Chamberlains were committed for trial. The trial commenced on 13 September 1982 and on 29 October they were found guilty ( $R v$ Chamberlain; see generally Brown \& Wilson 1992:119-141).

1 For example see The Honourable Justice Nader, as cited in Finlay 2003, p 14. 
The Chamberlains appealed to the Federal Court on 29 April 1983, but the convictions were upheld (Chamberlain and Another $v$ R). A further appeal to the High Court was made, and on 22 February 1984, by majority of three to two, the High Court rejected the appeal (Chamberlain v R (no. 2); see also Brown \& Wilson 1992:134). In June 1985, a direct application was made to the Northern Territory Government for an inquiry, which was ultimately rejected (Brown \& Wilson 1992:137). After the discovery of the remains of Azaria's jacket at the base of Ayers Rock on 2 February 1986, a Royal Commission was announced and Lindy Chamberlain was released from prison five days later on 7 February. The Commission ran into 1987, and the report was released on 2 June 1987, with Justice Morling's recommendation that the jury should have been directed to acquit (Morling 1987).

The Chamberlains then applied to the Northern Territory Supreme Court to have their convictions quashed. On 15 September 1988, eight years after the disappearance of their daughter and six years after their original convictions, they were finally exonerated (Chamberlain, Re Conviction of).

\section{Kelvin Condren}

\section{Brief Summary}

Kelvin Condren, an Indigenous Australian, falsely confessed during a police interrogation to murdering Patricia Mary Carlton. He was convicted and imprisoned for seven years for the murder despite the fact that he could not have committed the crime, as he was already in police custody at the time the offence occurred ( $R v$ Condren, ex-parte Attorney General of Qld; Hulls 2003; see generally Brown \& Wilson 1992:159-176).

\section{Exoneration Process}

Following his 1984 conviction, Condren appealed to the Queensland Court of Criminal Appeal on 2 March 1987. This appeal was rejected (Condren $v R$ ). Subsequently, new witnesses surfaced and it was argued that the new evidence was of sufficient quality to justify a second appeal. However, on 8 May 1989, the court rejected the option of a retrial, on the basis that the evidence was not deemed 'fresh', as it could have been presented at the original trial (Brown \& Wilson 1992:164). On 7 July 1989 Condren applied to the Governor of Queensland for a pardon, but this was rejected. The Attorney General stated that he would not refer the case back to the Court of Appeal (Brown \& Wilson 1992:171). In 1989 Condren appealed to the High Court, however in a separate matter a few weeks prior to Condren's appeal, a High Court decision was delivered confirming that the High Court could not accept new or fresh evidence (Mickelberg $v R$; see also $R v$ Condren, ex parte Attorney General). Condren's appeal was therefore adjourned. The Queensland Director of Public Prosecutions, however, agreed to bring the evidence to the attention of the Attorney General. There was a shift in politics, and the new Attorney General immediately referred the whole case back to the Queensland Court of Criminal Appeal ( $R v$ Condren, ex parte Attorney General; Brown \& Wilson 1992:173).

The order of the Court in June 1990, by a two to one majority, was that Condren's conviction be quashed, and that he be allowed a new trial $(R v$ Condren, ex parte Attorney General). On 29 June 1990, Condren's lawyer presented to the Attorney-General submissions outlining the case as to why Condren should not have to endure a new trial, and the Attorney General agreed, leaving Kelvin Condren finally exonerated (Brown \& Wilson 1992:174). 


\section{John Button}

\section{Brief Summary}

John Button in Western Australia, was convicted of the manslaughter of his girlfriend Rosemary Anderson. While he spent approximately five years incarcerated for this crime, he spent almost four decades fighting to prove his innocence. Button discovered Anderson lying wounded on the side of the road. After racing her to a doctor he was subjected to an intense police interrogation. During this interrogation a false confession was made, but was retracted shortly afterwards. (Button 1998:29-31; ABC TV 2002).

Subsequently, a known and convicted serial killer, Eric Edgar Cooke, later on several occasions confessed to the murder of Anderson providing full details of the incident. At a time when Australia still incorporated the death penalty, Cooke's final of several confessions to this murder was given moments before he was hanged for the other murders that he committed. These other murders had occurred in a similar way to that of Anderson, but despite this, Button's conviction remained (Blackburn 2001:1-3).

\section{Exoneration Process}

Convicted on 4 May 1963, Button launched an appeal which was based on Cooke's confession. However, the appeal was dismissed on 22 May 1964 (Button v The Queen). An application to the High Court for special leave to appeal was also refused on 14 September 1964 (as cited in Button v The Queen). In 1967 Button was released having served his prison term.

In 2001, a book detailing Button's case was released, bringing his case to the attention of the public and resulting in parliamentary pressure for an inquiry (Blackburn 2001). Button's appeal was heard via a reference by the Attorney General for a prerogative of mercy and on 25 February 2002, following a thirty-eight year fight to prove his innocence, the Western Australian Supreme Court of Appeal finally allowed Button's appeal and quashed his conviction (Button v The Queen; ABC TV 2002).

Achieving an exoneration is neither a quick nor easy process. The vast majority of innocence-based claims that proceed to appeal, will have evidence of their innocence uncovered subsequent to their conviction and appeal, just as occurred in the above cases. Investigation of claims of wrongful conviction will often take many years. The extreme frustration for those wrongly convicted is further exacerbated by the difficulty in achieving another appeal once evidence of innocence is finally uncovered. The vast majority of people claiming to be innocent in Australia are entirely reliant on the current appellate and pardon provisions for their potential release and exoneration. They are without the high public profile or political pressures which tend to motivate inquests or inquiries into the cases, such as with the Chamberlain and John Button cases.

The following section analyses the current mechanisms available for the correction of wrongful conviction, with the specific focus on corrective provisions for innocence-based appeals, and explores the adequacy of these measures. 


\section{Current Mechanisms and Institutions for the Correction of Wrongful Conviction in Australia}

\section{The Appeals System in Australia}

By virtue of Australia's Constitution, each State or Territory is essentially responsible for its own criminal law, both in substance and procedure. The Commonwealth also has a limited power to legislate regarding criminal matters, but this power is extremely narrow as it is restricted to the specific categories enunciated in Australia's Constitution. (Commonwealth of Australia Constitution Act 1900 s51). Australia's appeal provisions were adopted from England in the early $20^{\text {th }}$ century. Since then, England itself has made substantial changes to widen review of convictions but Australia has not (Criminal Appeal Act 1995 (United Kingdom) (c.35); Urbas 2002:144). The majority of appeals from serious criminal offences will be heard in the respective State Courts of (Criminal) Appeal. ${ }^{2}$ Generally appeals from these courts go to Australia's highest court, the High Court of Australia, if leave is granted for such an appeal. ${ }^{3}$ However, as discussed below, the inability of the High Court to hear fresh evidence of innocence greatly impacts on their role in the correction of actual innocence applicants.

\section{Right to an Appeal}

In Australia there is no automatic right to an appeal based on factual innocence. Only appeals based on law alone will qualify for such a legislative right to an appeal. If factual issues are involved, even if questions of law also arise, the leave of the Court is required before an appeal will be heard. ${ }^{4}$ Innocence based appeals will often be factually based, usually relying on newly gained evidence of innocence. Any such evidence is often the aim of investigative activities undertaken by Innocence Projects and other similarly minded organisations, whose role it is to investigate claims of wrongful conviction with the goal of uncovering new evidence of innocence and securing the release of wrongfully convicted people. (see generally, Weathered 2003). While the judiciary is likely to entertain appeals based on factual innocence, the right to an appeal based on law but not on facts, is indicative of the legislative priority given to claims of legal or procedural errors over those of actual innocence.

The general rule is that appeals must be applied for within one month of the date of conviction or sentence. ${ }^{5}$ Uncovering new evidence of innocence will be extremely rare within such a short time frame and thus, very few cases that go to appeal within the time

2 Criminal Appeal Act 1912 (New South Wales) s5F; Crimes Act 1958 (Victoria) s567; Criminal Code Act 1924 (Tasmania) s401; Criminal Code of the Northern Territory of Australia s 410; Criminal Code Act Compilation Act 1913 (Western Australia) s688; Criminal Law Consolidation Act 1935 (South Australia) s352; Criminal Code Act 1899 (Queensland) s 668D; Federal Court of Australia Act 1976 (Commonwealth) sections 24 \& 32A; Judiciary Act 1903 (Commonwealth) ss39, 39A.

3 Judiciary Act 1903 (Commonwealth) s35

4 For example, s 668D(1) of the Queensland Criminal Code provides: 'A person convicted on indictment ... may appeal to the Court - against the person's conviction on any ground which involves a question of law alone; and with the leave of the Court, or upon the certificate of the Judge of the court of trial that it is a fit case for appeal, against the person's conviction on any ground of appeal which involves a question of fact alone, or question of mixed law and fact, or any other ground which appears to the Court to be a sufficient ground of appeal; and with the leave of the Court, against the sentence passed on the person's conviction.'

5 For example, Criminal Code Act 1899 (Queensland), s 671; Criminal Appeal Act (New South Wales) 1912 s10 (1)(a); Crimes Act 1958 (Victoria) s572 (1); Criminal Code Act 1924 (Tasmania) s407 (1); Criminal Code of the Northern Territory of Australia s417 (1); Criminal Code Act Compilation Act 1913 (Western Australia) s695 (1). 
limit will be supported by new evidence of innocence, but rather will be likely to proceed on issues that were raised about aspects of the trial itself. The vast majority of cases that come to the attention of Innocence Projects (which aim to investigate claims of wrongful conviction with the goal of uncovering new evidence of innocence and achieving an exoneration $)^{6}$ will already have had and lost their appeal. Those few cases where the appeal was not exhausted would require an extension to the appeal time limitation. This extension needs to be applied for and granted by the courts, ${ }^{7}$ and would generally take place alongside an application to have the appeal heard based on fresh evidence.

\section{Standard for overturning convictions}

\section{Unreasonable or unsafe verdict}

The standard applied by Australian courts for the overturning of convictions on the basis of innocence will be, in essence, that the conviction is unreasonable, unsafe or cannot be supported by the evidence. For an example of a legislative provision see: Criminal Code Act 1899 (Qld) s 668E(1), 'Determination of appeal in ordinary cases', which provides:

The Court on any such appeal against conviction shall allow the appeal if it is of opinion that the verdict of the jury should be set aside on the ground that it is unreasonable, or cannot be supported having regard to the evidence, or that the judgment of the court of trial should be set aside on the ground of the wrong decision on any question of law, or that on any ground whatsoever there was a miscarriage of justice, and in any other case shall dismiss the appeal. (See also Ratten $v$ The Queen-at 515; Whitehorn $v$ The Queen at 688).

In determining whether a conviction is unreasonable, unsafe or cannot be supported by the evidence, judges are required to determine whether 'it was open to the jury to be satisfied beyond reasonable doubt that the accused was guilty' ( $M v$ The Queen at 493). The test to be applied by the appeal courts was explained by the High Court in $M v$ The Queen at 494, by Mason CJ, Deane J, Dawson J and Toohey J as follows:

In most cases a doubt experienced by an appellate court will be a doubt which a jury ought also to have experienced. It is only where a jury's advantage in seeing and hearing the evidence is capable of resolving a doubt experienced by a court of criminal appeal that the court may conclude that no miscarriage of justice occurred. That is to say, where the evidence lacks credibility for reasons which are not explained by the manner in which it was given, a reasonable doubt experienced by the court is a doubt which a reasonable jury ought to have experienced. If the evidence, upon the record itself, contains discrepancies, displays inadequacies, is tainted or otherwise lacks probative force in such a way as to lead the court of criminal appeal to conclude that, even making full allowance for the advantages enjoyed by the jury, there is a significant possibility that an innocent person has been convicted, then the court is bound to act and to set aside a verdict based upon that evidence. ${ }^{8}$

In determining whether a conviction should safely stand, Justice Kirby has noted the 'extreme difficulty which appellate judges face in finding the time to consider all, and I mean all, of the evidence at the trial in order to decide whether a conviction should safely stand or must be set aside and a new trial ordered' (Kirby 2000:55).

6 For a fuller discussion on the role of Innocence Projects, please see: Weathered (2003).

7 For example see: Crimes Act 1958 (Victoria) s572 (1); Criminal Appeal Act 1912 (New South Wales) s10 (1)(b); Criminal Code Act 1924 (Tasmania) s407 (5); Criminal Code Act 1899 (Queensland) s671 (3); Criminal Code of the Northern Territory of Australia s417 (2); Criminal Code (Western Australia) s695 (1); Criminal Law Consolidation Act 1935 (South Australia) s357 (2).

8 This test was later affirmed in Jones $v$ The Queen at 450-451. 
The Australian courts considered the potential adoption of the 'lurking doubt test', operative in the United Kingdom. ${ }^{9}$ The lurking doubt test essentially interprets a conviction as 'unsafe' through a lower standard and more subjective judicial sense of the case. It was enunciated in Reg $v$ Cooper at 271 per Widgery LJ as follows:

[I]n cases of this kind the court must in the end ask itself a subjective question, whether we are content to let the matter stand as it is, or whether there is not some lurking doubt in our minds which makes us wonder whether an injustice has been done. This is a reaction which may not be based strictly on the evidence as such; it is a reaction which can be produced by the general feel of the case as the court experiences it. ${ }^{100}$

This test, was however, ultimately rejected by the High Court with the higher standard applying as outlined in M v The Queen.

The Court also has the ability to dismiss an appeal even if the appeal grounds are satisfied, if it invokes 'the proviso'. The proviso allows for the conviction to stand, despite successful appeal points, if the court is of the belief that 'no substantial miscarriage of justice' has ultimately occurred. For example, section 668E (1A) of the Queensland Criminal Code provides:

However, the Court may, notwithstanding that it is of the opinion that the point or points raised by the appeal might be decided in favour of the appellant, dismiss the appeal if it considers that no substantial miscarriage of justice has actually occurred.

Generally, Australian appeal courts have traditionally demonstrated a reluctance to overturn jury verdicts, leading to some criticism suggesting a failure by the judiciary to properly carry out their function in the correction of wrongful convictions (Brown 1997:239).

\section{Miscarriage of Justice}

The 'miscarriage of justice' ground also has some potential application for innocence appeals. Typically, this provision has been narrowly interpreted as allowing the court an additional power to be used with caution in an extremely narrow range of cases, to set aside a conviction that essentially fails to meet the 'unreasonable or not supportable on the evidence' ground (Brennan, J, Chamberlain v The Queen at 604).

The case of Easterday $v$ The Queen highlights where the miscarriage ground may be utilised where the prosecution fails to disclose all relevant evidence to the defence. Generally in Australia, the Crown has a duty to disclose relevant information to the accused. For example, s26 of the Queensland Prosecutorial Guidelines states 'The Crown has a duty to make full and early disclosure of the prosecution case to the defence'. (s26 Qld Department of Public Prosecutions Guidelines). The duty is also subject on rare occasions to the 'overriding demands of justice and public interest' (s26(viii) Qld Department of Public Prosecutions Guidelines). The police and prosecutors exercise an element of discretion as to what is 'relevant'. In 2000, a New South Wales Law Reform Commission Report noted that its research and consultations indicated that pre-trial prosecution disclosure was generally complied with but not always complete (New South Wales Law Reform Commission 2000). Withholding of such information can impact on the right to a fair trial, as shown in the Easterday case.

9 Ratten v The Queen; Whitehorn v The Queen; $M v$ The Queen.

10 Reg. $v$ Cooper at 271 (Widgery, LJ); This has since been approved in Stafford $v$ Director of Public Prosecutions at 892. 
In that case, three amateur gold prospectors were convicted of defrauding a gold mining company out of six million dollars. It was alleged that they had 'salted' (tampered) their soil tests with gold dust, resulting in a false reading of the proportion of gold contained within their claim (Easterday v The Queen; Coulthart 2003). It was later discovered that the Crown had earlier withheld important documents from the defence and court at trial, which indicated other people who may have benefited from the salting through insider trading. Roberts-Smith J commented, (Easterday $v$ The Queen):

This is not a case in which the non-disclosure of the report, or the new or fresh evidence the subject of the grounds of appeal, shows the appellants to be innocent or must have raised such a doubt in the mind of a reasonable jury that the verdict should not be allowed to stand ... nor even that it might raise a significant possibility that a jury acting reasonably, would have acquitted the appellants ... nor that their effect was so fundamental as to lead to the conclusion there was no proper trial at all ... The point here, it seems to me, is whether there has been a miscarriage of justice because without the evidence being available to the defence there was not a fair trial of the appellants.

It is also arguable that an applicant could utilise this 'miscarriage' ground through highlighting the use of particularly fallible evidence such as eyewitness identification evidence (Chamberlain v The Queen at 600-611).

\section{Fresh evidence appeals}

As noted, innocence based claims will often rest on newly uncovered evidence of innocence, such as for example, DNA results that were not available at the time of the original trial or appeal. Legislative provisions do allow for the reception of 'fresh' evidence, if certain criteria are satisfied. ${ }^{111}$

'Fresh' evidence, as distinguished simply from 'new' evidence, is newly uncovered evidence that did not exist at the time of trial or which could not have been uncovered with due diligence at the time of the trial (Ratten $v$ The Queen; Gallagher $v$ R). If evidence was reasonably available but not presented at trial, then the fresh evidence requirement of due diligence will not be satisfied and the right to an appeal may be lost (Ratten $v$ The Queen; Gallagher $v$ R).

Such is the interplay between the fresh evidence appeal rights and inadequate counsel. Firstly, failure to uncover or present evidence of innocence at trial may result in the conviction of an innocent person. If such evidence would have been presented at trial by a lawyer acting with due diligence, the applicant may additionally be prevented from presenting such evidence at appeal, as it may not satisfy the due diligence requirement demanded prior to the receipt of fresh evidence. As such the applicant is doubly punished.

The applicant may therefore wish to appeal on the ground of inadequate counsel, however, the laws in this country make it difficult to succeed on that basis. The basic standard for a claim of inadequate counsel in Australia is 'flagrant incompetence'. As such, the conduct of counsel must be deemed so far outside the standard of competency to be reasonably expected of counsel, as to have caused or appear plainly likely to have caused a miscarriage of justice ( $R v$ Birks at 392).

11 For example see: ss 671, 668 \& 669 Queensland Criminal Code Act 1899; Criminal Appeal Act 1912 (New South Wales) s12; Crimes Act 1958 (Victoria) s574; Criminal Law Consolidation Act 1935 (South Australia) s359; Criminal Code (Northern Territory) s419; Criminal Code Act Compilation Act 1913 (Western Australia) s697; Criminal Code Act 1924 (Tasmania) s409 (1). Also see Federal Court Of Australia Act 1976. 
However, new persuasive evidence of innocence may be sufficient to displace this due diligence requirement, as outlined by Barwick, J in Ratten $v$ The Queen at 517:

Of course, if by reason of new evidence accepted by it though it may not be fresh evidence, the court is either satisfied of innocence or entertains such a doubt that the verdict of guilty cannot stand, the fact that the trial itself has been fair will not prevent the court upon that evidence quashing the conviction.

\section{The States' legislative restriction to one appeal}

The current legislative appeal provisions in Australia have been interpreted as allowing the appeal courts jurisdiction to hear one appeal only, thereby providing no right to a second or additional appeal (Grierson $v R$ ).

Despite this, evidence of innocence arriving after an unsuccessful appeal, according to our current system, is insufficient to give an innocent person the right to a second hearing in the state appellate courts. This restriction is arguably highly problematic for innocent but convicted persons as the remaining alternative potential options for review, such as a High Court appeal or application for pardon, are so limited.

\section{The High Court}

The High Court of Australia is the highest court to which an appeal, with the leave of the Court, may be brought. However, here again, a question of innocence can be left unanswered due to the jurisdictional limitations of the High Court. The High Court has repeatedly held that it cannot receive fresh evidence, due to its constitutional boundaries of being a strictly appellate court, as set out in section $73-76$ of the Australian Constitution (Mickelberg v The Queen; Eastman v The Queen. For dissenting judgments see Deane J in Mickelberg $v$ The Queen; Kirby J in Eastman v The Queen at 85). While it has been argued that the Constitution allows for the reception of fresh evidence, the High Court has maintained that the receipt of fresh evidence would alter the court's jurisdiction from appellate, to original.

As such, the High Court is unable to receive new or fresh evidence. As noted by Kirby, $\mathrm{J}$ in Sinanovic's Application at 451, this would inevitably be the case even where DNA evidence of innocence was available subsequent to the applicant's exhaustion of their one appeal:

By the authority of this Court such fresh evidence, even if it were to show a grave factual error, indeed even punishment of an innocent person, cannot be received by this court exercising this appellate jurisdiction ... A good instance of the discovery of such fresh evidence recently arose in the court of appeal of Queensland ... There DNA evidence, discovered after trial and before the hearing of the appeal in that Court, conclusively demonstrated that the prisoner was innocent. However, if such evidence were discovered between the hearing in the State or Territory appellate court and this Court ... it could not be received. The prisoner would be bereft of protection by the Judicature. He or she would be compelled to seek relief from the Executive.

That Australia's highest court cannot release an innocent person from prison because of a jurisdictional inability to receive the new evidence of innocence, is likely to be considered abhorrent by those adhering to more commonly held concepts of justice. For factually innocence-based applicants with new evidence of innocence who previously exhausted their one state level appeal, the pardon process is the only remaining avenue to which they may apply in an attempt to correct their wrongful conviction. 


\section{Executive Powers: Pardon/Prerogative of Mercy}

A petition for a pardon must go to the Governor of a State ${ }^{12}$ or other relevant executive body who may, inter alia, issue a pardon as an executive decision (which does not operate as an exoneration but merely relieves the petitioner from the consequences of the conviction), or more importantly refer the case to the Court of Appeal. ${ }^{13}$ Virtually no guidelines exist as to when, why or how the decision on whether or not to refer the case to the Court of Appeal is made. A letter stating that the application for pardon has been unsuccessful (i.e. the case has not been referred to the Court of Appeal) may be the extent of disclosure regarding the entire process. This process is non-transparent and purely discretionary. Further, the reliance on the executive for referral to the Court of Appeal leaves the process open to political considerations and public pressure, is insufficiently independent from the original wrongful conviction and is arguably a breach of the doctrine of the separation of powers.

For those cases that are successful in obtaining a referral from the Governor, the Court of Appeal, while once again under a duty to consider the whole case (subject to appellate restrictions), will generally not receive or consider evidence already adjudicated upon nor admit evidence that fails to satisfy the fresh evidence criteria, as outlined earlier with respect to appeals. ${ }^{14}$

\section{Part 13A, New South Wales}

New South Wales differs from other Australian states, offering the most extensive postconviction avenue for appeal in Australia. An expanded appeal avenue was incorporated into New South Wales in 1993, following a review of their old appellate provisions (the ones similarly currently applying in the rest of Australia). ${ }^{15}$ The review was conducted after a spate of wrongful convictions from across the country (and England) were exposed. ${ }^{16}$

Under the new provisions, a pardon petition need not necessarily go to the Governor in New South Wales. While this option remains, Part 13A of the Crimes Act 1900 (New South Wales) s474, additionally and alternatively allows for an application to go directly to the Supreme Court. Either the Governor or Supreme Court may direct that an inquiry, similar to that of a Royal Commission, take place. From 1994 to September 2003, there were 69 applications to the Supreme Court under part 13A of the Crimes Act. Of these, seven inquiries were directed and/or heard. As at September 2003, there were six applications awaiting hearing. Five cases resulted in convictions being quashed by the Court of Criminal Appeal and one re-trial ordered (Finlay 2003:13).

12 Australia Act 1986 s7 (1) \& (2): 'Powers and functions of Her Majesty and Governors in respect of States (1) Her Majesty's representative in each State shall be the Governor. (2) ... all powers and functions of Her Majesty in respect of a State are exercisable only by the Governor of the State'.

13 For example, see: Criminal Code Act I899 (Qld), s 18 (Royal Prerogative of Mercy) and s 672A; Crimes Act 1958 (Victoria) s584; Criminal Law Consolidation Act 1935 (South Australia) s 369; Sentencing Act 1995 (Western Australia) s140; Criminal Code Act 1924 (Tasmania) s419; Crimes Act 1900 (Australian Capital Territory) s433; Crimes Act 1900 (New South Wales) s474B and ss474C - G which slightly extends the pardon provision by alternatively allowing for an application to go to the Supreme Court; Criminal Code of the Northern Territory of Australia 4431.

14 Mallard v The Queen [2003] WASCA 296; $R$ v Gunn (No 2) (1942) 43 SR (NSW) 27; R v Sparkes [1956] 2 All ER 245.

15 See the Issues Paper: Review of s 475 by the Criminal Law Review Division of the New South Wales Attorney General's Department; see also Brown, Ferrier, Neal \& Weisbrot, 1996, pp $307-308$.

16 As outlined in Brown et al., 1996 p 308, these included Anderson, Alister and Dunn, Splatt, Ziggy Pohl, Douglas Rendell, Alexander McLeod-Lindsay, Arthus Loveday and in England, the Birmingham Six and Guildford Four. 


\section{Royal Commissions}

Royal Commissions have played a crucial role in correcting a small number of wrongful convictions. ${ }^{17}$ The Executive has the power to order a Royal Commission into a claim of wrongful conviction and recommendations resulting from Royal Commissions are highly influential. For example, it was the recommendations from the Chamberlain Royal Commission (discussed earlier) that eventually resulted in the overturning of Chamberlain convictions in the Northern Territory Supreme Court. In another example, Charles Edward Splatt, who spent six years in prison in South Australia after being wrongly convicted of murder, had his conviction overturned by the South Australian Court of Appeal, the day following such a recommendation from the Shannon Royal Commission that was conducted into his case. ${ }^{18}$

Two of the valuable features of Royal Commissions stem from their ability extensively to examine claims of wrongful conviction, with the potential of not only gaining evidence of innocence but additionally and importantly, exposing the causes of the wrongful conviction. Unfortunately, their employment is often associated only with high profile or highly publicised cases. Most wrongful conviction applicants are more likely to be lost and forgotten and will not stimulate sufficient media or other attention to ignite a royal commission into their case. As such, Royal Commissions are an inadequate mechanism to resolve the difficulties involved in achieving an exoneration for the vast majority of innocent applicants.

\section{Conclusion}

This article has pointed to the disturbing frequency with which wrongful convictions have been uncovered in the United States, while noting that wrongful conviction is not restricted to that country. It is important for Australia to recognise that wrongful conviction has and will continue to occur in this country, and as such the corrective mechanisms for cases of wrongful conviction in Australia are inadequate.

The restriction to one appeal within the state Courts of Appeal, regardless of subsequent evidence of innocence, is particularly concerning because the other potential options for exoneration are so deficient as to be virtually non-existent. Further, the traditional higher appellate option, the High Court of Australia, is unable to hear fresh evidence. As such it is powerless to release an innocent person who appeals based on new evidence of innocence.

The restrictive jurisdictional ambits of the appellate courts place great weight on the pardon provision as the measure for referral and correction of wrongful conviction. The pardon process is discretionary, non-transparent and insufficiently independent to be receiving, monitoring and deciding on claims of wrongful conviction. It relies on an executive body whose authority in dealing with claims of wrongful conviction is contrary to the traditional doctrine of separation of powers. Further, it is potentially subject to political and public pressure.

The combination of difficulties outlined in this paper, and lack of real access to appellate courts, is not only unsatisfactory for innocent but convicted people, but it plainly fails to fulfil commonly held concepts of justice. To maintain the pardon provision now as the only real avenue for innocent but convicted persons, signals complacency regarding the plight of the wrongly convicted. To better enable the correction of wrongful conviction, improved access to the courts for persons with new evidence of innocence is imperative.

17 For a discussion on the wider role of Royal Commissions of Inquiry please see Gilligan 2002, pp 289-30.

18 Splatt was exonerated in 1984. Please see Shannon 1984. 


\section{List of Cases}

Button v The Queen [2002] WASCA 35 (25 Feb 2002).

Button v The Queen, unreported; CCA SCt of WA; 22 May 1964.

Chamberlain and Another v R (1983) 46 ALR 493.

Chamberlain v R (no. 2) (1984) 153 CLR 521.

Chamberlain, Re Conviction of (1988) 93 FLR 239.

Condren v R (1987) 28 A Crim R 261.

Easterday v The Queen [2003] WASCA 69 (28 March 2003).

Eastman v The Queen (2000) 172 ALR 39.

Gallagher v R (1986) 160 CLR 392.

Grierson v R (1938) 60 CLR 431.

Jones v The Queen (1997) 191 CLR 439.

Mv The Queen (1994) 181 CLR 487.

Mallard v The Queen [2003] WASCA 296.

Mickelberg $v$ The Queen (1989) 167 CLR 259.

$R v$ Birks (1990) A Crim R 385.

$R v$ Chamberlain 29/10/1982 SCNT Unreported.

$R v$ Condren ex-parte Attorney General of Qld [1991] 1 QDR 574).

$R v$ Gunn (no 2) (1942) 43 SR (NSW) 27.R v Sparkes [1956] 2 All ER 245.

Ratten v The Queen (1974) 131 CLR 510.

Reg v Cooper [1969] 1 QB 267.

Sinanovic's Application (2001) 180 ALR 448.

Stafford v Director of Public Prosecutions [1974] AC 878.

Whitehorn v The Queen (1983) 152 CLR 657.

\section{Legislation}

Australia Act 1986.

Commonwealth of Australia Constitution Act 1900.

Crimes Act 1900 (Australian Capital Territory). 
Crimes Act 1900 (New South Wales).

Crimes Act 1958 (Victoria).

Criminal Appeal Act 1995 (United Kingdom) (c.35).

Criminal Appeal Act 1912 (New South Wales).

Criminal Code Act 1899 (Queensland).

Criminal Code Act 1924 (Tasmania).

Criminal Code Act Compilation Act 1913 (Western Australia).

Criminal Code of the Northern Territory of Australia.

Criminal Law Consolidation Act 1935 (South Australia).

Federal Court Of Australia Act 1976.

Judiciary Act 1903 (Commonwealth).

Queensland Department of Public Prosecution Guidelines.

Sentencing Act 1995 (Western Australia).

\section{References}

ABC TV (2002) 'Murder He Wrote', Australian Story, ABC-TV, 5 August.

Blackburn, E (2001) Broken Lives, Hardie Grant Books, South Yarra, Victoria.

Brown, D (1997) 'The Chidiac Case', Alternative Law Journal, vol 22, no 5, pp 237-247.

Brown, D, Farrier, D, Neal, D \& Weisbrot, D, (1996) Criminal Laws: Second Edition, The Federation Press, Leichhardt, NSW.

Brown, M, \& Wilson, P (1992) Justice and Nightmares: Successes and Failures of Forensic Science in Australia and New Zealand, New South Wales University Press, Kensington.

Button, J (1998) Why Me Lord! The John Button Story, The Digital Document Company, Burswood Western Australia.

Coulthart, R (2003) 'Karpa Gold Fall Guys', Sunday, Channel Nine, May 18, 2003.

Criminal Cases Review Commission (2005) 28 October, <http://www.ccrc.gov.uk>.

Criminal Cases Review Commission (CCRC) (2003) Annual Report 2002-2003, Criminal Cases Review Commission, Birmingham, UK.

Finlay, M (2003) Review of the NSW Innocence Panel, September.

Gilligan, G (2002) 'Royal Commission of Inquiry', Australian and New Zealand Journal of Criminology, vol 35, no 3, December, pp 289-30. 
Hulls, R (1992) 'Opening Address', Australian Institute of Criminology Conference Proceedings, No. 21: Aboriginal justice issues : proceedings of a conference held 23-25 June, <http://www.aic.gov.au/publications/proceedings/21/openadd.pdf>.

Innocence Project (2005) 28 October, <http://www.innocence.org>.

Kaufman, F (1998) The Commission on Proceedings Involving Guy Paul Morin, Publications Ontario, Ontario, Canada.

Kirby, M (2000) 'Remedying Miscarriages of Justice in the Criminal Justice System', The Commonwealth Lawyer, pp 45-57.

New South Wales Law Reform Commission (2000) The Right To Silence, Report 95, New South Wales Law Reform Commission, Sydney.

Odgers, SJ \& Richardson JT (1995) 'Keeping Bad Science out of the Courtroom - Changes in American and Australian Expert Evidence Law', University of New South Wales Law Journal, vol 18, no 1, pp 108-129.

Royal Commission on Criminal Justice Report (1993) (Cm.2263) Her Majesty's Stationery Office, London.

Morling, TR (1987) 'Report of the Commissioner', Royal Commission of Inquiry into Chamberlain Convictions, NT.

Shannon, C (1984) Royal Commission Report concerning the Conviction of Edward Charles Splatt, Government Printer, South Australia.

Urbas, G (2002) 'DNA Evidence in Criminal Appeals and Post-Conviction Inquiries: Are New Forms of Review Required?', Macquarie Law Journal, vol 2, pp 141-164.

Weathered, L (2003) 'Investigating Innocence: The Emerging Role of Innocence Projects In The Correction of Wrongful Conviction in Australia', Griffith Law Review, vol 12, no 1, pp 64-90. 